\title{
Academic career of young scientists: Motivations and professional roles
}

\author{
Olga Ya. Gerasimova', Viktoriya I. Kryachko² \\ ${ }^{1}$ Southern Federal University, Rostov-on-Don, Russia \\ ${ }^{2}$ National Research University Higher School of Economics, Moscow, Russia
}

\begin{abstract}
The paper investigates the problems of human capital reproduction in higher school. Falling effectiveness of graduate school underlie the research interest in the way, in which motivations for entering a doctoral program affect the choice of young scientists and lecturers about their career development and professional roles in the academic environment. Methodologically the study relies on Vroom's expectancy theory of motivation, as well as theoretical approaches to analyzing the motives behind embarking on a doctorate and the role in academia. The information base includes the results of a survey of 1,429 graduate students from five Russian federal universities. Applying multinomial logistic regression, the authors test the hypothesis that each of the professional roles (tutor, researcher and administrator) is dependent on an individual set of motivations for entering graduate school. The choice of the professional role is largely conscious and independent. Graduates who prefer the roles of tutor and researcher are usually motivated towards this type of activity and interested in benefits of the higher education system, such as flexible working hours, stable pay, etc. The career of researcher exhibits a wider range of motivations and is more sustainable in comparison with the others. The choice of the administrator role is typical of those entering higher school by inertia. The results of the study allow us to identify key motives of graduate students behind choosing particular professional roles. This is of value when formulating the applicant selection policy in accordance with the goals of the university and needs of society and the state.
\end{abstract}

Keywords: human capital of higher education; tutor roles; academic labour market; postgraduate education; multinomial logistic regression; motivations to enter graduate education.

JEL Classification: I23, J24

Funding: The reported study was funded by the Russian Foundation for Basic Research (RFBR), project number 18-010-00591 A "Choice of career strategies by graduate students".

Paper submitted: October 24, 2019

For citation: Gerasimova O.Ya., Kryachko V.I. (2019). Academic career of young scientists: Motivations and professional roles. Upravlenets - The Manager, vol. 10, no. 6, pp. 77-87. DOI: 10.29141/2218-5003-2019-10-6-7.

\section{INTRODUCTION}

Currently, Russia is beset with the problem of research personnel reproduction: during 2010-2018, the number of graduate students decreased by $42.3 \%$; the number of Russian organizations involved in PhD programs - by $22.1 \%$; the number of graduate students who defended their dissertations in a timely manner - by $56.5 \%$ (in 2018 , only $12.4 \%$ of PhD students managed to do that) ${ }^{1}$.

At the plenary meeting of the Russian Rectors'Union Congress, the Russian President Vladimir Putin stressed:"It is critically important for Russia to focus its resources on supporting talented, goal-oriented researchers and lecturers and to create optimum conditions so that the best Russian and foreign scholars, as well as promising university graduates, aspire to work in the Russian higher school.". Such trends emerge in response to objective and subjective conditions that hamper academic-pedagogical activities of graduate students.

Human capital of higher education can be interpreted as a combination of knowledge, skills and abilities of scientificpedagogical employees that are effectively used in research and educational activities of the university and increase its

\footnotetext{
${ }^{1}$ Federal State Statistic Service. Section: Science and Innovation. Available at: http://www.gks.ru/wps/wcm/connect/rosstat_main/rosstat/ ru/statistics/science_and_innovations/science/.

${ }^{2}$ The verbatim report on the plenary meeting of the Russian Rectors' Union Congress. Available at: http://www.kremlin.ru/events/president/ news/57367/print
}

intellectual and monetary capital. The fundamental difference between the human capital of educational institutions and that of manufacturing companies is that it creates not material products, but the new human capital of society. The common source of human capital of scientific-pedagogical staff at a university is students enrolled in Bachelor, Master and specialist degree programs; the basic source is graduate education programs aimed at training staff for higher school.

The great relevance of the problem of human capital reproduction in higher education and the theoretical-methodological basis underlie the purpose of the present study: to identify the core factors of PhD students' primary motivation behind entering graduate education in accordance with their preferences regarding the main professional roles in the academic job market. This market embraces the job markets of universities, research institutions and academy of sciences, whereas academic career is being employed and performing particular professional roles (tutor, researcher and administrator) for these structures. In the given research, primary motivation is seen as students' motives to enter a doctorate study. A study of the motivational pattern of potential academic employees' professional roles is especially useful when improving the supply management mechanisms in the academic job market, minimizing costs and increasing the effectiveness of graduate education programs. 
To accomplish the stated purpose, we complete the following objectives: firstly, to examine and systematize the theoretical approaches of Russian and foreign researchers to analyzing the motivation behind entering the graduate school programs and the role in the academic environment; secondly, to discuss the professional roles in the academic job market; thirdly, using multinomial logistic regression, to investigate the combination of motives behind entering graduate education that guide young scientists' choice in terms of certain professional role in the academic sphere.

The authors suppose that each of the existing professional roles (tutor, researcher and administrator) is predetermined by an individual set of motivations behind engaging in the academic environment, where the roles of tutor and researcher imply creative expression, while the role of manager involves career-centered vision. This hypothesis was formulated not only on the basis of analysis of the current research in the field of human capital reproduction in higher education, but also on the results of preliminary research, i.e. conducting a foresight session and an expert survey.

The contribution of the given article to the totality of scholarly publications on the academic job market is the focus of the motivational pattern in relation to the major professional roles present in the field of higher education.

\section{THEORETICAL AND METHODOLOGICAL BASIS OF STUDING MOTIVATIONS BEHIND ENTERING GRADUATE EDUCATION AND THE ROLES IN THE ACADEMIC ENVIRONMENT}

A number of researchers address the problem of research personnel reproduction and increasing the effectiveness of the graduate education management. Finkelshtein et al. [2014, pp. 22-25] reveal the career prospects for young specialists in the academic market and identify the quantitative and qualitative factors of demand and supply for young tutors. Osipov and Savenkov [2014, pp. 6-40, 58-62] analyse the demand and supply factors in the academic job market and the opinions of graduate students about their future career. Bednyi, Rybakov and Sapunov [2017, pp. 125-134] raise the question of motivation and professional aspirations of Russian graduates and look at the overall state of affairs in graduate education, its purpose, funding model, structure and program content. Applying qualitative methods of analysis, Terentyev, Bekova and Maloshonok [2018, p. 33] discover three central problems of graduate school (poor quality of graduate enrollment, poor quality of scientific advising and insufficient financial support for graduate students) and propose possible measures to resolve them. The present research is premised on Vroom's expectancy theory of motivation that relates to process theories. According to the theory, the primary motivating factor is expectancy of an individual that their behaviour will produce the desired outcome.

Russian and foreign researchers pay peculiar attention to analyzing the motivations behind entering the graduate education programs. The first factor is the desire of doctoral students to do research on the topic that they find interesting [Salmon, 1992; Brailsford, 2010; Leonard et al., 2005;
Baytiyeh, Naja, 2011a, 2011b; Churchill, Sanders, 2007]. This factor implies the strive to acquire research skills and solve some pressing problems. Such aspirations are referred to as personal agenda and research as politics [Churchill, Sanders, 2007, pp. 15-16]. Stern [2004] believes that "a taste for science" is inherent in young scientists.

The second motivation is the development of a career path [Churchill, Sanders, 2007; Gill, Hoppe, 2009; Brailsford, 2010; Leonard et al., 2005; Peters, Daly, 2013]. According to Brailsford [2010, p. 25], the primary motive behind starting a doctorate is "a strong commitment to the dissertation topic itself coupled with a desire to reach the summit of academic achievement." Terentyev, Bekova and Maloshonok [2018, p. 37] find that the initial motive for starting a $\mathrm{PhD}$ is a desire to pursue a career both inside and outside the academic job market.

The third motivation is personal motivating factors [Churchill, Sanders, 2007; Dust, 2006; Wellington, Sikes, 2007; Leonard, Becker, Coate, 2005]. Researchers distinguish between the following personal reasons: a need for a change in life [Dust, 2006; Wellington, Sikes, 2007]; pursuing a doctorate for the purpose of self-enrichment (with little or no extrinsic motivation) [Gill, Hoppe, 2009]; a sense of identity, i.e. pride in belonging to academic society and profession [Salmon, 1992; Akerlof, Kranton, 2010]; opportunity for personal fulfillment and self-development [Leonard, Becker, Coate, 2005; Lambie, Vaccaro, 2011]; draft deferment and a room in a student dormitory [Sizykh, 2014, p. 99; Bekova et al., 2017]; networking [Sizykh, 2014, p. 100]. According to Leonard, Becker and Coate [2005], for some doctoral students, their personal development and intellectual interest outweigh their professional aspirations. The researchers emphasize the "strong aspiration of a PhD student," which is based on the motives of "personal growth" and "advanced training" [Leonard, Becker, Coate, 2005, p. 139].

The fourth motivating factor is the previous experience, such as participation in research studies [Donnelly, 2011; Simon, 2010] or internship programs [Simon, 2010], as well as drifting in [Churchill, Sanders, 2007; Sizykh, 2014, p. 100]. According to Churchill and Sanders [2007], drifting in means doing something by inertia, i.e. a natural sequence of events after completing education of the previous stage.

The fifth factor is the decision to enrol in a PhD program influenced by third parties - family members, friends, colleagues and employers [Onwuegbuzie et al., 2014; Tanaka, Watanabe, 2012; Gardner, 2010; Lovitts, 2001; Ferguson, 2009; Hancock, 2007; Sizykh, 2014, p. 99].

The sixth motivation is getting a PhD degree due to its prestige [Dust, 2006; Leonard, Becker, Coate, 2005; Stubb, Pyhalto, Lonka, 2012; Sizykh, 2014, p. 99].

The seventh factor is better career and employment prospects [Brailsford, 2010; Leonard, Becker, Coate, 2005; Stubb, Pyhalto, Lonka, 2012; Wellington, Sikes, 2007; Sizykh, 2014, p. 99]. For the Russian graduate school model, Lyz and Labyntseva [2019, p. 70] highlight three motives for entering a doctoral program - material, professional and creative; the 
central idea behind them is an opportunity for $\mathrm{PhD}$ candidates to increase their competitiveness.

Adriana Wiegerováa [2016, p. 126] distinguishes external and internal motivations for continuing to graduate school. External motivations encompass implementing someone else's ideas, authority, receiving income for people lacking work experience, etc.; internal motives are the desire to become a researcher, be highly qualified in the chosen domain, get to a university, extend student life, etc. University is also an important factor for doctoral students when choosing whether to apply for a doctorate: talented students are already successful and in high demand during their study.

Gill and Hoppe [2009, p. 31] identify five motivational profiles that can lead an individual to doctoral study: traditional (entry to academia); advanced entry (professional development); continuing development (professional advancement, career enhancement); transition (entry to new career); and personal fulfillment (self-enrichment).

Research studies by Russian scholars demonstrate that, in addition to the desire to engage in research activity, graduate students express such primary motivation as aspiration to go into teaching [Bekova et al., 2017; Osipov, Savinkov, 2014]. It is worth noting that there is no such motivation emphasized in overseas studies.

Academia has its specificity: academic staff is free to choose their research fields and occupation. Alongside with the role of teacher, a lecturer can also act as a tutor, researcher and administrator [Gerasimova, 2017, p. 232].

1. Tutor (counselling lecturer) creates a comfortable learning environment that allows students to follow their own education path, provides students with pedagogical assistance and academic advice while taking into account their individuality and interests when preparing a lesson and content. The tutor's interaction with students can take the form of the following algorithm: understanding the uncertainty of the current situation by a student; setting time frames; planning stages and actions to achieve specific goals; maintaining independence in making decisions and from other people's opinions; analyzing, evaluating and reviewing the decisions taken in liaison with the tutor; building and coordinating partnerships with people and communities (organizations) to solve their own problems; assessing the results of their activities and the implementation of goals and objectives [Yanovskiy, 2016, p. 116].

Tutor-student interaction can be divided into several stages: motivational-targeted, accompanying and cogitative. At the first stage, a student's needs and interests are established, the current situation is assessed, goals and objectives are formulated, and short- and long-term plans of the individual education path are jointly constructed. At the second stage, the tutor provides pedagogical support and advice, reveals the student's potential and his/her abilities; the tutor and the student discuss the learning process, preliminary results and problems faced by the student, and, if necessary, the plan is adjusted. At the third stage, the results are analysed and future prospects are discussed.
However, it should be borne in mind that the individual education path implies an independent choice by the student, and the tutor's job is only to direct and advise. The tutor's main task is to help students understand themselves and teach them to resolve problems during the university study on their own. The tutor's activity is aimed at stimulating conditions for independent learning and development in accordance with the student's individual expectations. The tutor establishes partner relationships with students, gives psychological support during the study, organizes their educational activities and represents students' academic interests.

2. Tutor-researcher should be familiar with the theoretical foundations of the pedagogical process, the methodology for conducting scientific and research work with students, be able to navigate through the flow of scientific information, modern pedagogical technologies, and innovative teaching methods. The research work of a university lecturer includes the preparation and defense of a doctorate; writing monographs, textbooks, teaching aids; preparation of theses, scientific event reports; publishing research articles; doing reviews; participating in the research work of the department, scientific seminars, scheduled academic programs and competitions; participating in scientific projects in collaboration with other research organizations and institutions; preparing projects to take part in competitions and grants, etc. The results of research work, including theoretical and experimental studies, are the basis for teaching disciplines and educational-methodical work in the fields of professional activity of university lecturers. Anisimova and Rakitina [2010, p. 139] interpret university lecturers' research competencies as "... the content of personal motivational competencies; competencies in decision-making, development and implementation of research programs; in the field of information technologies; competencies in self-control and adjustment of research activities." Lazarev and Stavrinova [2006, p. 9] argue that a lecturer, as a subject of research activity, should be qualified enough to decide whether the research topic is relevant, set clear and adequate research objectives, put forward hypotheses, do effective planning, and ensure its effective implementation and in-depth analysis. Preparedness to do research is a set of qualities necessary to perform the abovementioned functions that includes cognitive, motivational, guidance-related and operational components. According to Novikov and Novikov [2010, p. 61-65], research work can be individual and collective. The latter is the most effective, since it articulates the pluralism of scientific opinion.

A lecturer's research work implies fulfilling the task of raising the status of: science - in society; a particular university - in education rankings; a lecturer - in academia. Other tasks of research activity are to establish and develop schools of thought that link research work with society's needs; to promote academic cooperation between lecturers and students; to encourage their commitment and personal-professional fulfillment.

We suppose that, if a lecturer is not a professional researcher, they are unable to form students' competencies 
3. Tutor-administrator carries out administrative, methodical and organisational functions; is responsible for implementing the decisions of the department head and the dean; develops and approves the learning materials necessary to teach the academic disciplines. Career progression of a lecturer often results in joining the university's administration team. Administrative functions assigned usually have a negative effect on both teaching and research work, since they take all personal and time resources. Competency in organization reflects the ability of a lecturer to arrange their own pedagogical activity and student work. Tutorial competency is also among the tasks of tutor-administrators. Their influence spreads over all tutors, including those in the leading positions, e.g. preparing and designing work programs and teaching materials, working for public methodological authorities (methodological councils and committees), etc.

Tutors should distribute their working time in such a way to perform all the roles. At different stages of professional activity and depending on their goals, tutors can shift their priorities in favor of one particular role.

Thus, the importance of professional roles in the academic society makes it relevant to explore the motivations behind continuing to graduate school.

\section{RESEARCH METHOD}

The present research was carried out in several stages under the grant "A Choice of career strategies by graduate students" funded by the Russian Foundation for Basic Research (RFBR).

At the first stage, in 2018, the research team of the Faculty of Economics of the Southern Federal University held a foresight session "Prospects for the development of graduate school in federal universities". Within the framework of the session, the researchers asked the heads of graduate programs, university administrators, academic advisors, graduate students and young lecturers about the conditions that impeded the development of academic career.

According to the results of the focus group, all respondents identified the following conditions that hampered further scientific-pedagogical activities of graduate students: low funding (modest salary, minimum fringe benefits, small scholarship, and as a result the need to seek additional income while studying in graduate school); a shortage of doctoral advisors; the conditions of the corporate environment (irregular working hours, bureaucratization of the educational process, inadequate facilities); a difficult procedure of the

defense of the thesis; lack of a communication system between graduate students; lack of the value of science and the dissertation as an effectiveness indicator; uncertainty (career uncertainty, fixed-term contracts); ineffective entry barriers when entering graduate school.

At the second stage, based on the findings of the focus groups, a questionnaire consisting of 38 questions was prepared which aimed to draw a general portrait of graduate student and identifying the factors that shape their career strategy.

At the third stage, we interviewed 1,429 respondents from five federal universities: Kazan (Volga region) Federal University - $9.23 \%$; Northern (Arctic) Federal University named after M.V. Lomonosov - $13.96 \%$; North-Caucasus Federal University - $23.08 \%$; Siberian Federal University $16.29 \%$; and Sothern Federal University - $37.43 \%$. The survey involved $34.7 \%$ of graduate students in their first year of study; $30.6 \%$ in their second year; 28.4 and $6.4 \%$ - in their third and fourth years of study, respectively.

At the fourth stage, the data obtained were statistically processed. It was found that the most significant factors behind entering a doctorate included: the desire to engage in research and teaching; personal fulfillment and self-development in an area of interest to the respondent; and the prestige of enrolling for $\mathrm{aPD}$ and gaining a doctoral degree.

The intensity of these motives was determined by means of questionnaires. The informants were asked a question "Why did you start a doctorate?" and assessed each motive on a 10-point scale, where 1 - not important at all, and 10 crucially important.

As seen from Fig. 1, the factors "Additional competitive advantages in the non-academic job market" and "Networking opportunities and interesting contacts at the university" were slightly less motivating. The rest of the questions were not popular options among the respondents. Based on the foregoing, we can conclude that in most cases entering graduate school is a conscious decision that satisfies personal, professional and career needs of individuals.

Kendall's coefficient of concordance for the motives of potential young lecturers when enrolling for a $\mathrm{PhD}$ is 0.15 (the coefficient is significant in terms of Pearson's chi-squared test), which indicates a weak consistency of respondents' opinions ${ }^{1}$.

The question "Which role in the professional sphere do you prefer?" was designed to establish respondents' preferences in their expected career path. To answer this question, respondents were asked to choose among several options: 1) lecturer/tutor; 2) researcher/analyst; 3) administrator/manager; 4) entrepreneur/self-employed; 5) other (your answer). More than half of respondents (58.6\%) plan to further their careers in higher school. It is worth noting that after graduating a $\mathrm{PhD}$ program $39.0 \%$ of respondents would prefer the role of researcher or analyst. A third of respondents (30.0\%) would like to work as a lecturer/tutor. The roles of administra-

${ }^{1}$ The closer this value is to 0 , the lower the level of consistency. 


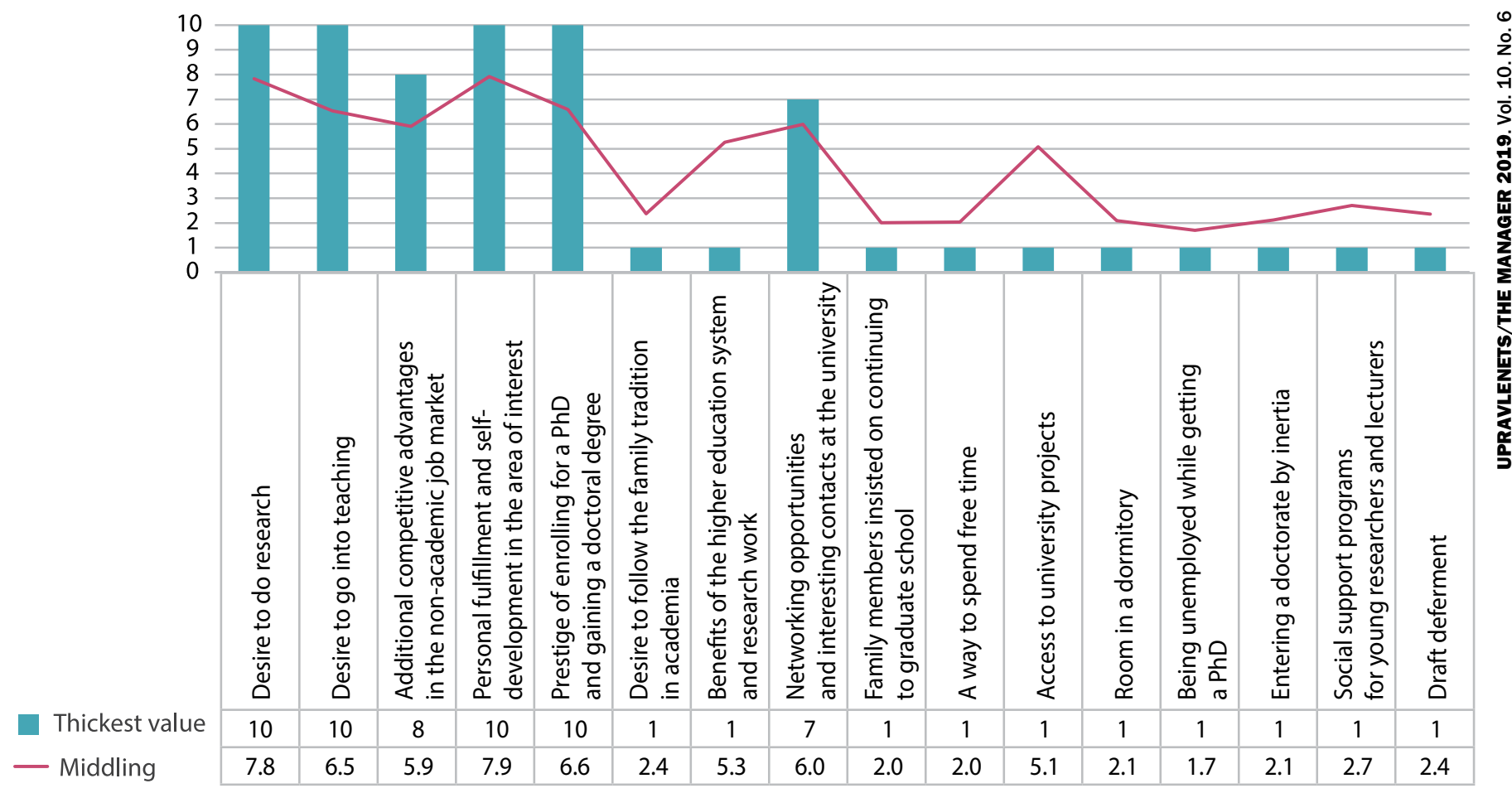

Fig. 1. The thickest value and the middling of motivations for becoming a PhD student ${ }^{1}$

Рис. 1. Мода и среднее по мотивам, которыми руководствуются молодые люди при поступлении в аспирантуру

tor/manager (10.0\%), entrepreneur/self-employed (13.0\%) and other $(7.0 \%)$ are significantly less popular among the graduate students surveyed (Fig. 2).

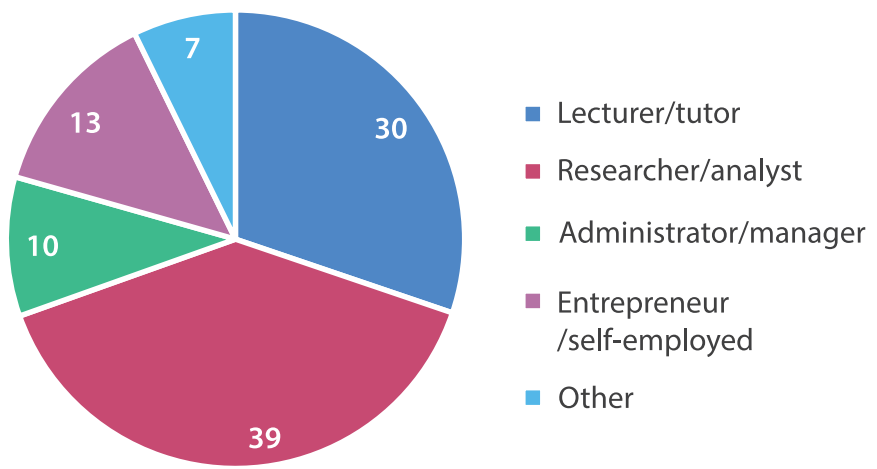

Fig. 2. Respondents' preferences in the professional roles in the academic job market, $\%^{2}$

Рис. 2. Предпочтение аспирантами профессиональных ролей на академическом рынке труда, \%

Nearly a quarter of respondents (24.0\%) who checked the "Other" option expressed their desire to combine teaching and research work: $18.0 \%$ of them specified that they would prefer the role of a developer or programmer, and $12.0 \%$ - of an engineer. At that, more than half of graduate students who plan to pursue a career of engineer would like to combine it with teaching. $10.0 \%$ of postgraduate students highlight that they aim to work as a head (not specifying the field of science and higher education). More than a third of

\footnotetext{
${ }^{1,2}$ Compiled by the authors according to the results of the sociological study.
}

informants (35.0\%) did not elaborate their answers. One graduate student described the following preferred professional role of the mixed type: "While working as an entrepreneur (self-employed), to conduct research in the field of law so as to share the acquired experience and expertise as a lecturer."

Thus, $1.7 \%$ of respondents consciously prefer to combine the main professional roles of teacher and researcher, and $0.8 \%$ of informants have a strong aspiration to combine teaching with a career outside of academia.

\section{EMPIRICAL RESEARCH RESULTS}

We have performed regression analysis in order to confirm the hypothesis that each of the professional roles (tutor, researcher and administrator) was determined by an individual set of motivations for entering graduate school, where creative motives prevailed for the roles of tutor and researcher, and career motives - for the role of manager. This method allows assessing the extent, to which a certain set of factors affects the variable under study: in the given paper, we can assess the extent, to which various motivations for entering a doctoral program determine graduates' preferences in professional roles in the academic job market. The choice of multinomial logistic regression for data analysis is due to the fact that, firstly, the dependent variable (professional roles) is category-based with unranked values, and secondly, the independent variables (graduates' motivations) are of qualitative nature.

In each of the four models, the dependent variable was respondents' desire or unwillingness to work as tutor, researcher or administrator in the field of science or higher ed- 
$\approx$ ucation, as well as any other positions outside of academia.

- The presented model of multinomial logistic regression clas-

o sifies the professional roles "Entrepreneur/self-employed"

and "Other" (excluding those who specified mixed roles) as

"Additional roles", i. e. positions outside of the academic job market. While calculating, the model with the dependent variable "Additional roles" was taken as the basic variable, so the equation for it was not derived. For the purpose of the current research, it is important to evaluate the motivations of graduates who anticipate to pursue an academic career.

The graduates with mixed preferences in the professional roles (from the group who chose "Other") are evenly distributed among the groups "Tutors" and "Researchers". Checking the descriptive statistics of this small group did not reveal heterogeneity in motivations for entering graduate school, which confirms the possibility of such a redistribution. It does not make sense to separate the group "Mixed roles" in the regression model, since this group is very small. The graduates who plan to combine a career of engineer with teaching belong to the group "Tutors".

Bias in models with such dependent variables are minimal, since the variable is the subjective preference of a respondent.
The model's factors were respondents' motives to enroll in a PhD program that have been discussed in the first part of the paper on the basis of the Russian and foreign literature analysis and expanded in terms of personal motivations revealed during face-to-face focus groups with experts in higher education and graduate students. The motivations included in the model borrowed the exact phrasing written in the questionnaires.

The multinomial logistic regression model of the role preferences in academia takes the following form:

$$
P\left(Z=j \mid X_{i}\right)=\frac{\exp \left(X_{i} \beta_{j}\right)}{\sum_{S=1}^{j}\left(\exp \left(X_{i} \beta_{s}\right)\right)} .
$$

The dependent variable takes on four values that correspond to the preferred professional roles of tutor, researcher, administrator and other $\{j=T, R, M, 0\}$. The group "Additional roles" is the basic variable (the value of the dependent variable is 0 ). Explanatory variables (regressors) are motivations of graduates $(X)$ presented on the left side of Table. The results of multinomial logistic regression, i. e. marginal effects relative to the corresponding regressands, are given on the right side of Table.

Results of multinomial logistic regression of the effect that motivations for entering graduate education exert on the roles preferences in the academic job market (marginal effects) ${ }^{1}$ Результаты мультиномиальной логит-регрессии влияния мотивов поступления в аспирантуру на предпочтение профессиональных ролей на академическом рынке труда (предельные эффекты)

\begin{tabular}{|c|c|c|c|}
\hline Factor (motivation) & 1 - Tutor & 2 - Researcher & 3 - Administrator \\
\hline Desire to do research & $-0.093(0.078)$ & $0.369 *(0.078)$ & $-0.042(0.096)$ \\
\hline Desire to go into teaching & $0.437^{*}(0.074)$ & $-0.134^{* *}(0.061)$ & $0.194^{* *}(0.085)$ \\
\hline $\begin{array}{l}\text { Additional competitive advantages in the non-academic job market (public } \\
\text { service, commerce) }\end{array}$ & $-0.055(0.061)$ & $0.026(0.056)$ & $0.095(0.078)$ \\
\hline Personal fulfillment and self-development in the area of interest & $0.085(0.080)$ & $0.030(0.073)$ & $-0.131(0.096)$ \\
\hline Prestige of enrolling for a $\mathrm{PhD}$ and gaining a doctoral degree & $0.001(0.069)$ & $-0.101(0.064)$ & $-0.030(0.088)$ \\
\hline Desire to follow the family tradition in academia & $-0.161^{* *}(0.073)$ & $-0.128^{* *}(0.071)$ & $0.006(0.079)$ \\
\hline $\begin{array}{l}\text { Benefits of the higher education system and research work (flexible schedule, } \\
\text { stable pay) }\end{array}$ & $0.185^{*}(0.066)$ & $0.150^{* *}(0.062)$ & $0.130(0.080)$ \\
\hline Networking opportunities and interesting contacts at the university & $-0.054(0.069)$ & $-0.040(0.063)$ & $-0.002(0.085)$ \\
\hline Family members insisted on continuing to graduate school & $-0.044(0.075)$ & $-0.204^{* *}(0.085)$ & $-0.053(0.090)$ \\
\hline A way to spend free time & $-0.092(0.103)$ & $0.156^{* * *}(0.093)$ & $-0.153(0.131)$ \\
\hline $\begin{array}{l}\text { Access to university projects (scholarships, internships, international mobility } \\
\text { programs) }\end{array}$ & $0.088(0.069)$ & $0.104^{* * *}(0.062)$ & $0.134(0.084)$ \\
\hline Room in a dormitory & $-0.150^{* *}(0.073)$ & $-0.149^{* *}(0.066)$ & $-0.198^{* *}(0.098)$ \\
\hline Being unemployed while getting a PhD & $0.088(0.107)$ & $-0.092(0.103)$ & $-0.156(0.150)$ \\
\hline Entering a doctorate by inertia & $0.135(0.088)$ & $-0.077(0.084)$ & $0.184^{* * *}(0.105)$ \\
\hline Social support programs for young researchers and lecturers (housing programs) & $0.051(0.078)$ & $0.062(0.073)$ & $0.037(0.092)$ \\
\hline Draft deferment & $-0.077(0.067)$ & $0.007(0.053)$ & $-0.036(0.079)$ \\
\hline Other & $0.194(0.139)$ & $0.021(0.139)$ & $0.125(0.173)$ \\
\hline Number of observations & \multicolumn{3}{|c|}{1,429} \\
\hline
\end{tabular}

Note. The values presented in Table characterize the extent to which motives behind entering graduate school affect the corresponding dependent variable (the choice of the professional role - tutor, researcher or administrator). Statistically significant values are marked with "*", "**" and "***" and indicate significance at the level of 1, 5 and $10 \%$, respectively (based on persistent standard errors given in brackets).

\footnotetext{
${ }^{1}$ Compiled by the authors according to the results of the study.
} 
The quality of the regression equation estimated for multinomial logistic regression through Pseudo $R^{2}=0.2279$ is good $^{1}$.

Obviously, the choice of a career of a tutor or researcher is dependent on the corresponding motive for entering graduate school, i.e. the desire to engage in research activities. This determines the choice of the role of researcher with a probability of $36.9 \%$. The desire to engage in teaching underlies the choice of the role of tutor with a probability of $43.7 \%$, but reduces the likelihood of choosing a researcher career by $13.4 \%$. The motive of teaching for potential researchers is statistically insignificant. Consequently, this choice is more frequent for those graduates who prefer to work as researchers, while tutors are more loyal to research activities.

Benefits of the higher education system (flexible schedule, stable pay) are attractive for the graduate students who prefer a career of a tutor: the choice of this motive increases the probability of becoming a tutor by $18.5 \%$.

A dormitory room and the desire to follow the family tradition in academia decrease the probability of choosing an academic career. This once again proves that graduate students, who choose a career path in higher education, do this consciously and exclusively for the purpose of professional fulfillment.

Regression analysis indicates there is quite a large number of motivating factors significant for preferring a career in research. In addition to the abovementioned motives, it is worth noting that such motives as "Benefits of the higher education system and research work" and "A way to spend free time" increase the likelihood of becoming a researcher by $15 \%$. The graduate students motivated by the factor "Access to university projects" are going to choose the role of researcher with a probability of $10.4 \%$. If family members insisted on starting a PhD, then with a probability of $20.4 \%$ the doctoral student would not choose a research career.

The choice of the role of administrator is determined primarily by two factors: "Desire to go into teaching" - $19.4 \%$, and "Entering a doctorate by inertia" - $18.4 \%$. Arguably, such graduate students are completely oriented towards a career in higher education, but are still uncertain about which path to follow - tutor or administrator, - since high motivation to engage in teaching is contrary to the role of administrator. For graduates who expect to get a dormitory room while doing a doctorate degree, the probability to choose the role of administrator decreases by $20 \%$.

\footnotetext{
${ }^{1}$ The coefficient value exceeds 0.2 , which in terms of real data can be estimated as a model of good quality that allows one to trust the resulting equation.
}

Such motivating factors as "Draft deferment", "Social support programs for young researchers and lecturers", "Networking opportunities and interesting contacts at the university" and "Additional competitive advantages in the non-academic job market" did not have statistical significance. Consequently, these factors in no way affect the choice of the role after graduation.

\section{CONCLUSION}

The research results allow, firstly, identifying the key motives of graduate students behind choosing a particular professional role, which is useful when formulating the policy of graduates' selection in accordance with the goals of the university, and, secondly, drawing a general portrait of modern doctoral student.

The authors' hypothesis that each of the professional roles (tutor, researcher and administrator) is determined by an individual set of motivations for entering graduate school, where creative motives prevail for the roles of tutor and researcher, and career motives - for the role of administrator, is partially confirmed. We found that for manager, as with tutor and researcher, career development factors aimed at obtaining competitive advantages in the job market and gaining prestige were not important. The position of administrator is preferable for graduates who enter a doctorate by inertia and are likely to combine administrative functions with teaching. The role of researcher is determined mainly by a stable intrinsic desire to engage in this type of activity and the availability of free time; the fact that "Access to university projects" is an important factor for doctoral students prove that they stick to an integrated approach when choosing their career path. The creative component of graduate students' motivation who prefer research activities could not be detected. Graduates who prefer the role of tutor are motivated by the desire to forge this career, as well as by the opportunities of working flexible hours and getting stable pay.

Hence, motivations behind entering graduate school affect the future self-identification of young scientists and the role they will perform in academia. Future researchers can be identified as early as the selection stage. From the perspective of the graduate school effectiveness, this particular category of graduate students is the key to achieving the strategic goals of the faculty, university and entire society, and, therefore, it is the most productive. That is why, in our opinion, it is necessary to carry out the so-called "screening" of graduate students during admission, based not only on their professional competencies, but also on their motivations for entering graduate school. 
Akerlof G., Kranton R. (2010). Identichnost'i ekonomika organizatsiy [ldentity and the economics of organizations]. Rossiyskiy zhurnal menedzhmenta - Russian Management Journal, vol. 8, no. 2, pp. 107-130.

Anisimova N.P., Rakitina O.V. (2010). Nauchno-issledovatel'skie kompetentsii kak novoobrazovaniya lichnosti prepodavatelya pedagogicheskogo vuza [Research Competences as New Formations of a Person of the Pedagogical Higher School Teacher]. Yaroslavskiy pedagogicheskiy vestnik. Psikhologo-pedagogicheskie nauki - Yaroslavl Pedagogical Bulletin. Psychological and Pedagogical Sciences, no. 4, vol. II, pp. 137-142.

Bednyi B.I., Rybakov N.V., Sapunov M.B. (2017). Rossiyskaya aspirantura v obrazovatel'nom pole: mezhdistsiplinarnyy diskurs [Doctoral education in Russia in the educational field: An interdisciplinary discourse]. Sotsiologicheskie issledovaniya - Sociological Studies, no. 9, pp. 125-134. DOI: 10.7868/S0132162517090148.

Bekova S.K., Gruzdev I.A., Dzhafarova Z.I., Maloshonok N.G., Terentyev E.A. (2017). Portret sovremennogo rossiyskogo aspirant [A portrait of a modern Russian graduate student]. Moscow: HSE Publishing house.

Gerasimova O.Ya. (2017). Rol' sistemy vysshego obrazovaniya v formirovanii chelovecheskogo kapitala molodezhi [The role of higher education system in the formation of youth human capital]. Gosudarstvennoe i munitsipal'noe upravlenie. Uchenye zapiski SKAGS - State and Municipal Management Scholar Notes, no. 3, pp. 227-234. DOI: 10.23394/2079-1690-2017-1-3-227234.

Lazarev V.S., Stavrinova N.N. (2006). Kriterii i urovni gotovnosti budushchego pedagoga k issledovatel'skoy deyatel'nosti [Criteria and levels of preparedness of a future teacher for research activities]. Pedagogika - Pedagogy, no. 2, pp. 51-59.

Lyz N.A., Labyntseva I.S. (2019). Spetsifika obucheniya v aspiranture: rol' motivatsii aspirantov [Peculiarities of PhD Training: The Role of Postgraduate Students' Motivation]. Vestnik VGU. Seriya: Problemy vysshego obrazovaniya - Proceedings of Voronezh State University. Series: Problems of Higher Education, no. 1, pp. 68-72.

Novikov A.M., Novikov D.A. (2010). Metodologiya nauchnogo issledovaniya [Academic research methodology]. Moscow: Librokom.

Osipov G.V., Savinkov V.I. (2014). Dinamika aspirantury i perspektivy do 2030 goda: statisticheskiy i sotsiologicheskiy analiz [Dynamics of postgraduate education and prospects until 2030: Statistical and sociological analysis]. Moscow: TsSP i M.

Sizykh A.D. (2014). Analiz akademicheskoy sredy kak mesta ucheby i raboty [Analysis of an academic environment as a place of studies and work]. Voprosy obrazovaniya - Educational Studies, no. 1, pp. 92-109.

Terentyev E.A., Bekova S.K., Maloshonok N.G. (2018). Krizis rossiyskoy aspirantury: istochniki problem i vozmozhnosti ikh preodoleniya [The crisis of postgraduate studies in Russia: What bears problems and how to overcome them]. Universitetskoe upravlenie: praktika i analiz - University Management: Practice and Analysis, vol. 22, no. 5, pp. 52-67. DOI: https://doi. org/10.15826/umpa.2018.05.049.

Finkelshtein M., Iglesias K., Panova A.A., Yudkevich M.M. (2014). Perspektivy molodykh spetsialistov na akademicheskom rynke truda [Prospects of young professionals in the academic labor market: Global comparison and assessment]. Voprosy obrazovaniya-Educational Studies, no. 2, pp. 20-43.

Yanovskiy L.M. (2016). T'yutor v vuze: deyatel'nost'i kompetentsii [Tutor at the university: Activities and competencies]. Sistema menedzhmenta kachestva: opyt i perspektivy - Quality Management System: Experience and Prospects, vol. 5, pp. 114-117.

Baytiyeh H., Naja M. (2011a). Attitudes toward pursuing doctoral studies in dngineering. Paper presented at the American Society for Engineering Education, Vancouver, BC, Canada.

Baytiyeh H., Naja M. (2011b). Factors influencing the decision to enroll in an Engineering PhD Program. Paper presented at the Frontiers in Education, Rapid City, SD.

Brailsford I. (2010). Motives and aspirations for doctoral study: Career, personal, and inter-personal factors in the decision to embark on a history PhD. International Journal of Doctoral Studies, vol. 5, no. 1, pp. 16-27. DOI: 10.28945/710.

Churchill H., Sanders T. (2007). Getting your PhD: A practical insider's guide. London: Sage Publications.

Donnelly A.E. (2011). Factors influencing career choices of underrepresented STEM PhD graduates. Paper presented at the American Society for Engineering Education, Vancouver, BC, Canada.

Dust T.J. (2006). Motivational influences to pursue graduate studies in secondary music education. Alberta Journal of Educational Research, no. 52, pp. 158-166.

Ferguson T. (2009). The «write» skills and more: A thesis writing group for doctoral students. Journal of Geography in Higher Education, no. 33, pp. 285-297. DOl: https://doi.org/10.1080/03098260902734968.

Gardner S.K. (2010). Contrasting the socialization experiences of doctoral students in high-and low-completing departments: A qualitative analysis of disciplinary contexts at one institution. The Journal of Higher Education, no. 81, pp. 61-81. DOI: https://doi.org/10.1080/00221546.2010.11778970.

Gill T., Hoppe U. (2009). The business professional doctorate as an informing channel: A survey and analysis. International Journal of Doctoral Studies, no. 4, pp. 27-57.

Hancock D.R. (2007). Effects of performance assessment on the achievement and motivation of graduate students. Active Learning in Higher Education, no. 8, pp. 219-231. DOI: https://doi.org/10.1177/1469787407081888.

Lovitts B.E. (2001). Leaving the ivory tower: The causes and consequences of departure from doctoral study. Lanham, Maryland: Rowman \& Littlefield.

Lambie G.W., Vaccaro N. (2011). Doctoral counselor education students' levels of research self-efficacy, perceptions of the research training environment, and interest in research. Counselor Education and Supervision, vol. 50, no. 4, pp. 243-258. DOI: https://doi.org/10.1002/j.1556-6978.2011.tb00122.x. 
Leonard D., Becker R., Coate K. (2005). To prove myself at the highest level: The benefits of doctoral study. Higher Education Research \& Development, vol. 24, no. 2, pp. 135-149. DOI: https://doi.org/10.1080/07294360500062904.

Peters D.L., Daly S.R. (2013). Returning to graduate school: Expectations of success, values of the degree, and managing the costs. Journal of Engineering Education, vol. 102, no. 2, pp. 244-268. DOI: 10.1002/jee.20012.

Salmon P. (1992). Achieving a PhD: Ten students' experience. Sterling, VA: Stylus Publishing, Inc.

Simon T. (2010). The road less traveled: Exploring factors that influence African Americans to pursue and complete doctoral degrees in Engineering and Applied Science disciplines. Paper presented at the American Society for Engineering Education, Louisville, KY.

Stubb J., Pyhalto K., Lonka K. (2012). The experienced meaning of working with a PhD thesis. Scandinavian Journal of Educational Research, vol. 56, pp. 439-456. DOI: https://doi.org/10.1080/00313831.2011.599422.

Stern S. (2004). Do scientists pay to be scientists? Management Science, vol. 50, no. 6, pp. 835-853. DOI: $10.3386 /$ w7410.

Onwuegbuzie A.J., Rosli R., Ingram J.M., Frels R.K. (2014). A critical dialectical pluralistic examination of the lived experience of select women doctoral students. Qualitative Report, vol. 19, pp. 1-35.

Tanaka M., Watanabea Y. (2012). Academic and family conditions associated with intrinsic academic motivation in Japanese medical students: A pilot study. Health Education Journal, vol. 71, pp. 358-364. DOI: https://doi.org/10.1177/0017896911401004.

Wellington J., Sikes P. (2007). «A doctorate in a tight compartment»: Why do students choose a professional doctorate and what impact does it have on their personal and professional lives? Studies in Higher Education, vol. 31, pp. 723-734. DOI: https:// doi.org/10.1080/03075070601004358.

Wiegerováa A. (2016). A study of the motives of doctoral students. Procedia-Social and Behavioral Sciences, vol. 217, pp. 123-131. DOI: 10.1016/j.sbspro.2016.02.043.

Information about the authors

Olga Ya. Gerasimova

Senior Lecturer of HR Management Dept. Southern Federal University (105/42 Bolshaya Sadovaya St., Rostov-on-Don, 344006, Russia). E-mail: osenkiv@sfedu.ru.

Viktoriya I. Kryachko

Graduate student of Faculty of Economics. National Research University Higher School of Economics (20 Myasnitskaya St., Moscow, 101000, Russia).E-mail: vi.kryachko@mail.ru.

\title{
Академическая карьера молодого ученого: мотивация и профессиональная роль
}

\author{
О.Я. Герасимова², В.И. Крячко ${ }^{2}$ \\ ${ }^{1}$ Южный федеральный университет, г. Ростов-на-Дону, РФ \\ ${ }^{2}$ Национальный исследовательский университет «Высшая школа экономики», г. Москва, РФ
}

Аннотация. Статья посвящена проблемам воспроизводства человеческого капитала высшей школы. Снижение показателей результативности аспирантуры обусловило исследовательский интерес к влиянию мотивации поступления в аспирантуру на принятие решений молодыми исследователями и преподавателями относительно своего профессионального развития и выбора роли в академической среде. Методологической базой исследования являются мотивационная теория ожиданий В. Врума, а также теоретические подходы к анализу мотиваций поступления в аспирантуру и ее роли в академической среде. Информационная база основана на результатах проведенного социологического исследования - опроса 1429 аспирантов из 5 федеральных университетов. Авторы подвергают проверке гипотезу о том, что каждая из существующих профессиональных ролей (тьютора, исследователя и администратора) определяется индивидуальным набором мотиваций входа в академическую среду и применяют для этого статистический метод - мультиномиальной логит-регрессии. Выбор академической среды в значительной мере выступает осознанным и самостоятельным. Предпочтение ролей преподавателя и исследователя определяется целенаправленной мотивацией к данным видам деятельности, интересом к особенностям работы в академической среде (гибкий график, стабильная зарплата и др.). Исследовательская стратегия имеет более широкий спектр мотиваций и более устойчива по сравнению с остальными. Выбор карьеры администратора характерен для поступивших в аспирантуру «по инерции». Результаты исследования позволяют выявить ключевые мотивы аспирантов в разрезе предпочтений профессиональных ролей, что имеет ценность при формировании политики отбора аспирантов в соответствии с целями вуза и запросами общества и государства.

Ключевые слова: человеческий капитал высшей школы; роли преподавателя; академический рынок труда; аспирантура; мультиномиальная логит-регрессия; мотивы поступления в аспирантуру.

JEL Classification: I23, J24

Финансирование: статья подготовлена при финансовой поддержке РФФИ в рамках научного проекта № 18-010-00591 А «Выбор карьерных стратегий аспирантами». 
Дата поступления статьи: 24 октября 2019 г.

Ссылка для цитирования: Герасимова О.Я., Крячко В.И. (2019). Академическая карьера молодого ученого: мотивация и профессиональная роль // Управленец. Т. 10. № 6. С. 77-87. DOI: 10.29141/2218-5003-2019-10-6-7.

\section{Источники}

Акерлоф Дж.А., Крэнтон Р.И. (2010). Идентичность и экономика организаций // Российский журнал менеджмента. Т. 8, № 2. С. 107-130.

Анисимова Н.П., Ракитина О.В. (2010). Научно-исследовательские компетенции как новообразования личности преподавателя педагогического вуза // Ярославский педагогический вестник. Психолого-педагогические науки. № 4(II). С. $137-142$.

Бедный Б.И., Рыбаков Н.В., Сапунов М.Б. (2017). Российская аспирантура в образовательном поле: междисциплинарный дискурс // Социологические исследования. № 9. С. 125-134.

Бекова С.К., Груздев И.А., Джафарова 3.И., Малошонок Н.Г., Терентьев Е. А. (2017). Портрет современного российского аспиранта // Современная аналитика образования. № 7(15). М.: НИУ ВШЭ.

Герасимова О.Я. (2017). Роль системы высшего образования в формировании человеческого капитала молодежи // Государственное и муниципальное управление. Ученые записки СКАГС. № 3. С. 227-234.

Лазарев В.С., Ставринова Н.Н. (2006). Критерии и уровни готовности будущего педагога к исследовательской деятельности // Педагогика. № 2. С. 51-59.

Лызь Н.А., Лабынцева И.С. (2019). Специфика обучения в аспирантуре: роль мотивации аспирантов // Вестник ВГУ. № 1. C. 68-72.

Новиков А.М., Новиков Д.А. (2010). Методология научного исследования. М. : Либроком.

Осипов Г.В., Савинков В.И. (2014). Динамика аспирантуры и перспективы до 2030 года: статистический и социологический анализ. М.: ЦСП и М.

Сизых А.Д. (2014). Анализ академической среды как места учебы и работы // Вопросы образования. № 1. С. 92-109.

Терентьев Е.А., Бекова С.К., Малошонок Н.Г. (2018). Кризис российской аспирантуры // Университетское управление: практика и анализ. № 22(5). С. 52-67.

Финкельштейн М., Иглесиас К., Панова А.А., Юдкевич М.М. (2014). Перспективы молодых специалистов на академическом рынке труда // Вопросы образования. № 2. С . 20-43.

Яновский Л.М. (2016). Тьютор в вузе: деятельность и компетенции // Система менеджмента качества: опыт и перспективы. Вып. 5. С. 114-117.

Baytiyeh H., Naja M. (2011a). Attitudes toward pursuing doctoral studies in dngineering. Paper presented at the American Society for Engineering Education, Vancouver, BC, Canada.

Baytiyeh H., Naja M. (2011b). Factors influencing the decision to enroll in an Engineering PhD Program. Paper presented at the Frontiers in Education, Rapid City, SD.

Brailsford I. (2010). Motives and aspirations for doctoral study: Career, personal, and inter-personal factors in the decision to embark on a history PhD. International Journal of Doctoral Studies, vol. 5, no. 1, pp. 16-27. DOI: 10.28945/710.

Churchill H., Sanders T. (2007). Getting your PhD: A practical insider's guide. London: Sage Publications.

Donnelly A.E. (2011). Factors influencing career choices of underrepresented STEM PhD graduates. Paper presented at the American Society for Engineering Education, Vancouver, BC, Canada.

Dust T.J. (2006). Motivational influences to pursue graduate studies in secondary music education. Alberta Journal of Educational Research, no. 52, pp. 158-166.

Ferguson T. (2009). The «write» skills and more: A thesis writing group for doctoral students. Journal of Geography in Higher Education, no. 33, pp. 285-297. DOl: https://doi.org/10.1080/03098260902734968.

Gardner S.K. (2010). Contrasting the socialization experiences of doctoral students in high-and low-completing departments: A qualitative analysis of disciplinary contexts at one institution. The Journal of Higher Education, no. 81, pp. 61-81. DOI: https:// doi.org/10.1080/00221546.2010.11778970.

Gill T., Hoppe U. (2009). The business professional doctorate as an informing channel: A survey and analysis. International Journal of Doctoral Studies, no. 4, pp. 27-57.

Hancock D.R. (2007). Effects of performance assessment on the achievement and motivation of graduate students. Active Learning in Higher Education, no. 8, pp. 219-231. DOI: https://doi.org/10.1177/1469787407081888.

Lovitts B.E. (2001). Leaving the ivory tower: The causes and consequences of departure from doctoral study. Lanham, Maryland: Rowman \& Littlefield.

Lambie G.W., Vaccaro N. (2011). Doctoral counselor education students' levels of research self-efficacy, perceptions of the research training environment, and interest in research. Counselor Education and Supervision, vol. 50, no. 4, pp. 243-258. DOI: https:// doi.org/10.1002/j.1556-6978.2011.tb00122.x.

Leonard D., Becker R., Coate K. (2005). To prove myself at the highest level: The benefits of doctoral study. Higher Education Research \& Development, vol. 24, no. 2, pp. 135-149. DOI: https://doi.org/10.1080/07294360500062904.

Peters D.L., Daly S.R. (2013). Returning to graduate school: Expectations of success, values of the degree, and managing the costs. Journal of Engineering Education, vol. 102, no. 2, pp. 244-268. DOI: 10.1002/jee.20012.

Salmon P. (1992). Achieving a PhD: Ten students' experience. Sterling, VA: Stylus Publishing, Inc.

Simon T. (2010). The road less traveled: Exploring factors that influence African Americans to pursue and complete doctoral degrees in Engineering and Applied Science disciplines. Paper presented at the American Society for Engineering Education, Louisville, KY.

Stubb J., Pyhalto K., Lonka K. (2012). The experienced meaning of working with a PhD thesis. Scandinavian Journal of Educational Research, vol. 56, pp. 439-456. DOl: https://doi.org/10.1080/00313831.2011.599422.

Stern S. (2004). Do scientists pay to be scientists? Management Science, vol. 50, no. 6, pp. 835-853. DOI: $10.3386 /$ w7410. 
Onwuegbuzie A.J., Rosli R., Ingram J.M., Frels R.K. (2014). A critical dialectical pluralistic examination of the lived experience of select women doctoral students. Qualitative Report, vol. 19, pp. 1-35.

Tanaka M., Watanabea Y. (2012). Academic and family conditions associated with intrinsic academic motivation in Japanese medical students: A pilot study. Health Education Journal, vol. 71, pp. 358-364. DOI: https://doi.org/10.1177/0017896911401004.

Wellington J., Sikes P. (2007). «A doctorate in a tight compartment»: Why do students choose a professional doctorate and what impact does it have on their personal and professional lives? Studies in Higher Education, vol. 31, pp. 723-734. DOI: https://doi. org/10.1080/03075070601004358.

Wiegerováa A. (2016). A study of the motives of doctoral students. Procedia - Social and Behavioral Sciences, vol. 217, pp. $123-131$. DOI: 10.1016/j.sbspro.2016.02.043.

\section{Информация об авторах}

\section{Герасимова Ольга Ярославовна}

Старший преподаватель кафедры управления человеческими ресурсами. Южный федеральный университет (344006, РФ, г. Ростовна-Дону, ул. Большая Садовая, д. 105/42). E-mail: osenkiv@sfedu.ru

\section{Крячко Виктория Игоревна}

Аспирант факультета экономических наук. Национальный исследовательский университет «Высшая школа экономики» (101000, РФ, г. Москва, ул. Мясницкая, д. 20). Email: vi.kryachko@mail.ru. 